\title{
Swamp Deer in Uttar Pradesh
}

\author{
Colin Holloway
}

In 1965 there were eleven populations of the already declining northern race of the swamp deer in Uttar Pradesh, in northern India; by 1972 eight of these had disappeared, either through habitat destruction, such as the planting of eucalyptus and cultivation, cropprotection shooting or poaching. Probably only the fact that the meat is tough and the skin poor have saved the deer from disappearing completely in the state. The author describes a brief survey he made in the summer of 1972, estimates numbers and status, describes the threats, and lists the immediate needs for a conservation programme. The author is Staff Ecologist with IUCN.

The swamp deer or barasingha Cervus duvauceli is confined to the Indian sub-continent. It is listed in the IUCN's Red Data Book of threatened species in the endangered category. Ellerman and Morrison-Scott (1951) distinguish two races: Cervus duvauceli $d u v a u c e l i$ in north and north-east India, and $C . d$. branderi in central India.

The northern race formerly occurred in swampy areas bordering dry deciduous forests throughout the Indus, Ganges and Brahmaputra river basins. By the mid-1960s, however, its range had diminished to parts of south-west Nepal, northern Uttar Pradesh, West Bengal and Assam (Schaller 1967). The writer investigated the status of this race in Uttar Pradesh between May 29th and June 4th 1972, but a variety of mishaps, largely due to the unavoidably short notice of the visit, reduced the effective working period to only four days.

\section{Decline of the Swamp Deer}

Schaller (1967) named eleven localities in Uttar Pradesh where swamp deer were known, or believed, to survive in 1965 . Now, only seven years later, eight of these areas need to be struck from the list for all practical purposes. In Jaulasal, Lalkua and Maldan sanctuaries the deer's habitat has been converted to Eucalyptus plantations; their populations had already been drastically reduced by poaching and it is unlikely that more than a handful now survive. Marchia and Ghola areas, and stretches of suitable habitat along the Ganges river, west of Bijnor and of Chandpur, have apparently been lost through cultivation, and there is some doubt as to whether or not the deer have occurred between Hardwar and Luksor for some time (M.H. Ansari; B.H. Hingorani; S.C. Sharma, pers. comm.). It is possible that a few individuals still survive in some of these areas, or indeed, elsewhere in the State, but the remaining herds in Uttar Pradesh are now effectively confined to four Forest Divisions on the Nepalese border: Pilibhit, North Kheri, South Kheri and Bahraich, practically all of which comprise reserved forests. 


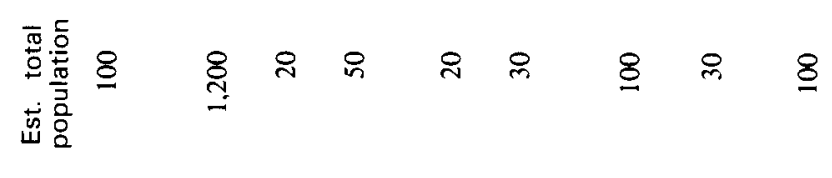

莺
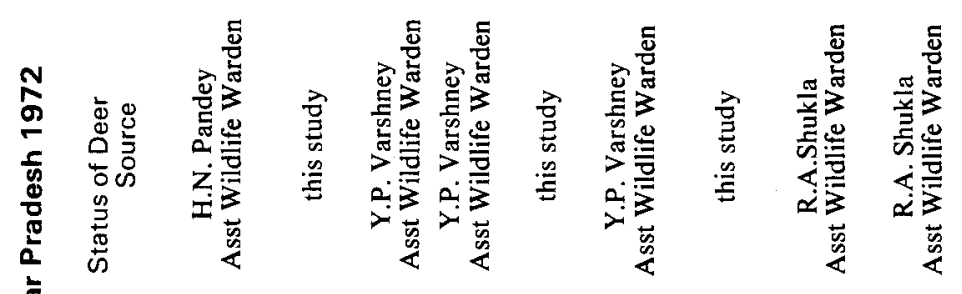

帚 ปั้ $\stackrel{\Xi}{ \pm}$

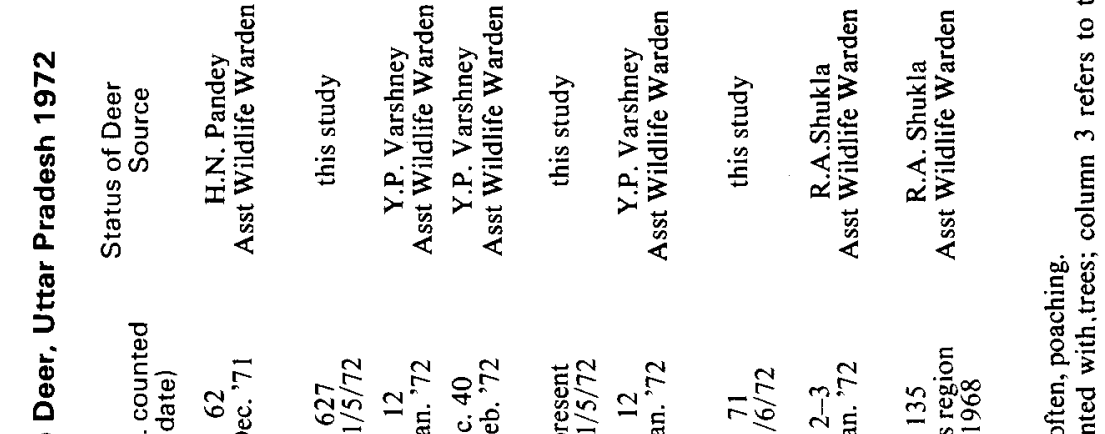

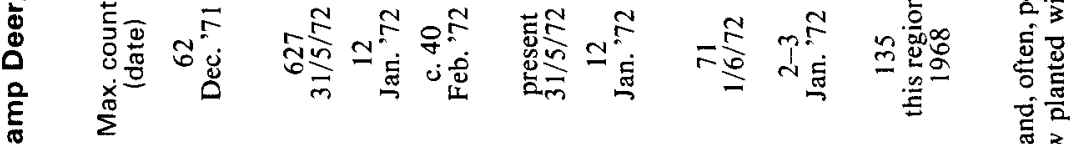

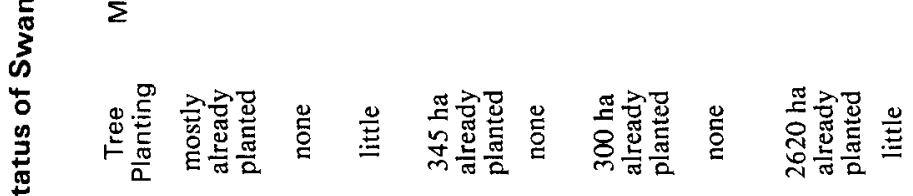
$\dot{s}$

$\frac{\frac{6}{6}}{\frac{0}{6}}$ 草

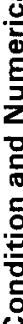

ํㅗㄴ

$\stackrel{+}{+10}$

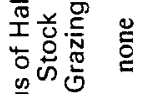

芯芯 苛

芯

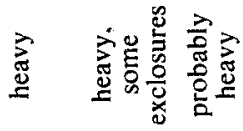

空

苾

旁导

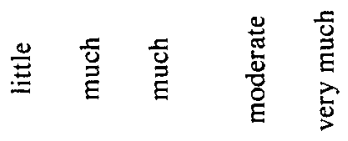

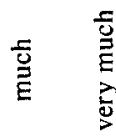

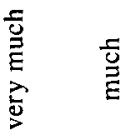

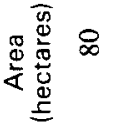

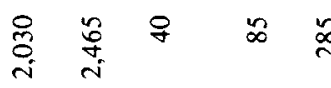

$\approx \stackrel{2}{\approx} \cong$

$\stackrel{\square}{\Xi}$

है

三苟

aํ

离

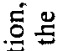

可

8

ช ำ

혼

ấ

흘

兘

乐事

茴

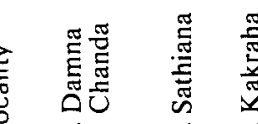

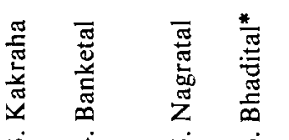

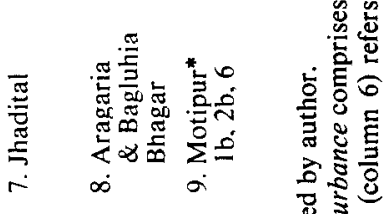

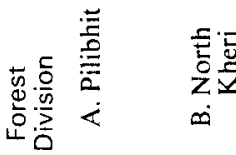

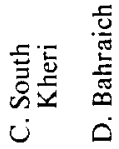

结 


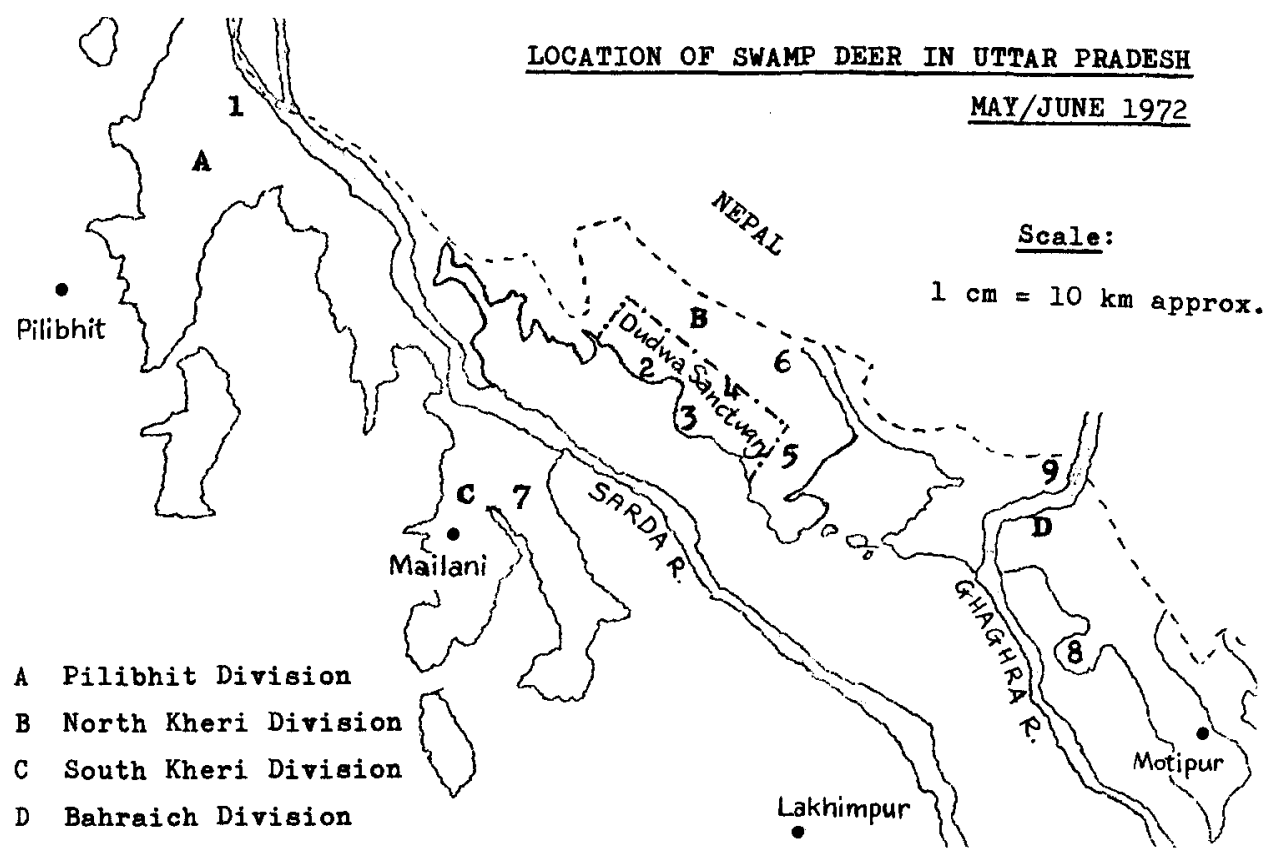

Detailed ecological data on the northern race of the swamp deer are lacking, but there is general agreement that access to swampy grasslands with free water is essential in the dry season, AprilJune. During the rains, July-September, however, the deer on the grassland fringes of the forest, at Dudwa, move from the flooded grasslands to better drained areas in cultivated land, whereas deer in forest glades apparently move into the woods. Most deer have returned to the grasslands by early March after the grass has been burned. The available evidence suggests that the swamp deer is primarily a grassland animal that has adapted to use of woodland in the rains and in winter where better drained grassland sites are not available.

The swamp deer's habit of aggregating in large herds in areas largely devoid of cover for at least three months of the year would probably have sealed its fate long ago if its carcase were more highly prized by the subsistence hunter. In fact, its meat is said to be tough and has a pungent flavour, and its skin is poor, even if carefully cured. Its principal value to the hunter is its head, as a trophy, and its antlers, which are used as screws in local boat building. Nevertheless, despite its limited value to the poacher, the weight of evidence suggests that hunting has been a major factor in seriously reducing the populations, either through poaching in reserved areas or killing animals at night on farmland, supposedly for crop protection.

The most significant threat to the animal's survival, however, is the destruction or modification of its habitat. Large areas of former habitat have been lost to cultivation (A. Singh 1970) and, more recently, suitable grassland areas in Forest Reserves are being lost to tree plantations. Shisham Dalbergia sissoo has been planted in 
grasslands for some decades, but with the introduction of Eucalyptus spp., grassland planting programmes in Uttar Pradesh have increased enormously since $1955 / 56$. The trees reduce the quantity of grasses by shade and almost certainly alter species composition. Although the wettest depressions in the grasslands (tals or shallow lakes) are not normally planted, ultimately the trees could dry out and colonise these depressions so that swamp deer would be unable to survive there. Further habitat loss has resulted from the permanent flooding of riverain grasslands by the construction of dams for irrigation projects. In Bahraich Forest Division, for example, some 1200 ha of Katarmian Ghat, in the north, are being deforested in the construction of a reservoir (the Sarda canal feeder project), started in 1970, and the area will be flooded in three or four years time. Formerly this was the main swamp-deer habitat of the Division; in 1968135 deer were counted (R.A. Shukla pers. comm.).

\section{Current Status and Location}

Table 1 summarises the location, habitat condition and estimated population sizes of swamp deer in the majority of the remaining areas known to harbour the species in Uttar Pradesh, in 1972. The Divisions (A-D) and localities (1-9) named in the table are shown on the map. Estimated population sizes are, for the most part, based on reported counts, sight or sign of animals found in this investigation, and the condition of habitat and surrounding areas. The possibility of the same groups of deer utilising more than one grassland area is considered to be remote, but cannot be entirely discounted.

Small remnant groups of swamp deer may still occur outside these Divisions. For example, a group of 4-5 deer has been seen on Khariya isthmus on the Duka nulla to the south west of Bahraich, between Doba Forest and Motipur; but the area is small (approximately $15 \mathrm{ha}$ ) and partially cultivated, and these animals are obviously doomed. Two further areas exist, however, in which sizeable groups may still remain. 'Vested forests', newly acquired by the Forest Department from private ownership, to the east of Pilibhit Division probably include both swampy grasslands and swamp deer. In the same region, to the north, a herd of some 150 deer were sighted on farmland in the Trans-Sarda area between the eastern forest boundary and the Nepalese border in 1969 (M.K. Ranjitsinh pers. comm.). There is no recent information on these animals, however, and, if they are still extant, their future is clearly precarious.

In summary, the total population of swamp deer in Uttar Pradesh would appear to be in the region of 1800-2000.

Sathiana block in Dudwa Sanctuary has by far the biggest herds of swamp deer in the State, very largely as the result of Mr Arjan Singh's efforts to restrict poaching, stock-grazing and other forms of disturbance. At the time of the writer's visit, virtually all male swamp deer had cast their antlers and regrowth of antlers in 'velvet' 
was about half completed in the older animals. A number of female deer were obviously pregnant and a few were sighted on their own in long grass (Saccrum spontaneum), suggesting that the birth of fawns was imminent. Herds were frequently clustered close together, and lying down by 0830 hours ( $3 \frac{1}{2}$ hours after sunrise). In the absence of stock-grazing, swamp grasses were often high and dense, and fawns could not be consistently distinguished from yearling females.

Three separate counts of swamp deer were undertaken in parts of Sathiana block, the results of which are shown in Table 2 .

The last count was interrupted by the apprehension of one of a gang of six poachers; it was necessary to return to Mr Arjan Singh's farm at speed and some deer were almost certainly missed in the latter half of the count. Counting from elephant was undoubtedly more efficient in locating most of the animals present. The counts from the vehicle suggest that stocking is lower in the southern sector than in the north, but not markedly so. The stocking of compartments 1 and 2 (the northern and southern halves of the western sector of the block) is generally agreed to be sparse, although some colonisation, in spite of poaching, is occurring. The evidence suggests a total population of some 1200 animals.

The only other area in which sizeable herds of swamp deer were seen was at Jhadital, in South Kheri Division, where a wildlife sanctuary has been proposed that would cover the northern half of the main forest area and comprise some $250 \mathrm{sq} \mathrm{km}$, including Jhadital grassland. A total of 71 swamp deer was seen in two herds of 24 and 47 that contained not fewer than 20 stags and approximately 16 fawns. The grassland is apparently treated as a type of sanctuary by local custom and the deer are rarely molested. At 0920 hrs on $1 / 6 / 72$ we watched the herd of forty-seven animals resting by the side of the tal, completely unconcerned about a herd of cattle and their herdsmen on the other side and the considerable noise from human traffic on a nearby road. The flight distance of these deer was no greater than that of animals in Sathiana.

In addition to having the largest population of swamp deer in the country, Dudwa Sanctuary also contains the only large, unplanted area of suitable swamp deer habitat in this region. The latter, from west to east, comprises Sathiana, Phersaia, Kakraha, and Gulra blocks (a total of $8100 \mathrm{ha}$ ) all within the Sanctuary, with buffer blocks of grassland in Belghat and Maholi blocks at either end, in one virtually continuous strip along the Division's southern edge.

It seems likely that the remarkably high density of swamp deer in Sathiana block (1:1.7 ha for nine months of the year) represents the natural ceiling for the area. Sathiana was estimated to contain over 1000 deer in 1969 (A. Singh 1970) and the estimate from the present study is only 1200 . In the absence of data on the deer's diet and forage preferences, it is impossible to make detailed comment on the condition of the habitat, but there is no obvious sign of overuse; the animals appear to be in good condition and healthy fawns are being reared. The most likely drain on population surplus is poaching, of which definite evidence exists, particularly in agricultural areas to 
Table 2. Swamp Deer Counts - Sathiana Block (Cpts. 1-5) Dudwa Sanctuary : May/June 1972

\begin{tabular}{|c|c|c|c|c|c|c|}
\hline Date & Area covered & Transport & $\begin{array}{l}\text { Distance } \\
\text { travelled }\end{array}$ & Time & $\begin{array}{l}\text { Effective } \\
\text { counting } \\
\text { time }\end{array}$ & $\begin{array}{l}\text { Total } \\
\text { deer } \\
\text { counted }\end{array}$ \\
\hline $30 / 5 / 72$ & $\begin{array}{c}\text { North } \\
\text { sector } \\
\text { Cots } 3.4 .5\end{array}$ & vehicle & $11 \mathrm{~km}$ & $1715-1900 \mathrm{hr}$ & $1 \frac{3}{4} \mathrm{hr}$ & 216 \\
\hline $31 / 5 / 72$ & $\begin{array}{l}\text { Cpts 3,4,5 } \\
\text { North } \\
\text { sector }\end{array}$ & elephant & $\begin{array}{r}14 \mathrm{~km} \\
\text { approx. }\end{array}$ & $0630-1030 \mathrm{hr}$ & $4 \mathrm{hr}$ & 627 \\
\hline $4 / 6 / 72$ & $\begin{array}{l}\text { Cpts } 3,4,5 \\
\text { South } \\
\text { sector } \\
\text { Cpts } 2,3,4,5\end{array}$ & vehicle & $11 \mathrm{~km}$ & $\begin{array}{l}1815-1830 \mathrm{hr} \\
1855-1910 \mathrm{hr}\end{array}$ & $\frac{1}{2} \mathrm{hr}$ & 143 \\
\hline
\end{tabular}

which the deer migrate in the rains (S.C. Sharma; A. Singh pers. comm.).

What is surprising is that, apart from the handful of deer in Kakraha, the neighbouring blocks to Sathiana are devoid of deer. These areas are subjected to heavy stock grazing and human disturbance, especially in Phersaia block, which contains the Ranjghat cattle station. Evidence from Jhadital, where deer density is lower (1:3.3 ha) but the animals are apparently thriving in spite of heavy stock grazing and disturbance, suggests that the deer can exist under these conditions, provided they are not actively harassed. Until the ecology and behaviour of the deer is studied, no firm conclusion can be drawn as to why the bulk of the Dudwa grasslands presently have no swamp deer, but present evidence suggests that if emigration from Sathiana does occur, effective colonisation is prevented by active persecution. Indeed, on the western edge of Sathiana, where deer densities are lowest, there is evidence of poaching by a Raisika caste of immigrant farmers, who reside outside the forest boundary, and by Tharoos, a caste of graziers, who stay in the north west corner of Sathiana block for nine months of the year by ancient right.

The only other sizeable areas of swamp deer habitat in the region are Aragaria, Bagluhia, and Motipur compartments $1 \mathrm{~b}, 2 \mathrm{~b}$ and 6 . However, unless the Wildlife Section of the Forest Department is to receive considerably more high-level support than it has enjoyed in the past, the contribution that these areas might make to the longterm conservation of the swamp deer is limited. Aragaria and Bagluhia are situated in a block of Forest Reserve that is surrounded on three sides by agricultural land (ref. map). Stock-grazing pressure is very high and the scope for poaching is, presumably, considerable. The Forest Department plan to plant the remaining grasslands in these blocks with eucalyptus, and it would require intervention at the highest level to alter these proposals. Motipur compartments $1 \mathrm{~b}, 2 \mathrm{~b}$ and 6 suffer not only from stock grazing, but also poaching by armed gangs of Nepalese from over the border. Darkness and a broken bridge prevented the writer from examining the Motipur compartments, but there is doubt about the suitability of some of this land for swamp deer. 
Pilibhit Division, on the other hand, may have greater potential for swamp deer than the information presented in Table 1 might suggest. In addition to the 'vested forests', which are presently an unknown quantity in regard to the deer, narrow strips of swamp (approximately $200 \mathrm{~m}$. wide), created by water seepage from canals emanating from the Sarda river and around a recently constructed reservoir to the north-east, provide new habitat for swamp deer and are apparently utilised by small groups. The grass in Damna Chanda (ref. Table 1) is primarily Imperata cylindrica, and the area is not typical swamp deer habitat in that it lacks permanent water, long grasses and reeds (such as Saccrum spp., Phragmites karka etc.), but it is utilised by a sizeable herd of deer that have access to a strip of canal seepage swamp to the north-east. One stag was seen in this area by the writer at 0842 hours on $2 / 6 / 72$, and a cast antler and large quantities of swamp deer faecal pellets ( 27 groups in two $230 \mathrm{~m}$. transects) were found.

\section{Conclusions}

1. The surviving herds of the northern race of the swamp deer Cervus d. duvauceli in Uttar Pradesh are, for all practical purposes, effectively confined to four Forest Divisions near the Nepalese border: Pilibhit, North Kheri, South Kheri and Bahraich. The total population is unlikely to exceed $1800-2000$.

2. North Kheri is the only Division that has a sanctuary for swamp deer (Dudwa); it contains the largest herd in India (approximately $1200)$ and the only large continuous area of suitable habitat $(8100$ ha). Within the sanctuary, virtually all the deer are restricted to one block (Sathiana), and colonisation of neighbouring blocks is apparently being prevented by poaching, stock-grazing and general human disturbance. The sanctuary does not provide year-round protection for the deer, which move on to agricultural land in the rains, where losses due to poachers are probably high.

3. The remaining herds within the State are small, relatively isolated remnants, which are worth preserving as an insurance against future calamity to the deer at Dudwa, but whose scope for expansion is often negligible because of reduction of their habitat by tree planting. Indeed, further decline of their numbers may be inevitable, as tree plantations mature and the quality of the habitat deteriorates.

4. There is scope for combining the conservation of the swamp deer and the tiger Panthera tigris tigris, another threatened species, in one programme, which would encompass North Kheri and Pilibhit Divisions. If suitable areas in Nepal could be included in the programme, including Sukla Phanta Reserve (a few miles north of Pilibhit), the reserve would cover an area well in excess of 2500 sq $\mathrm{km}$ and include the bulk of the world population of swamp deer.

5 . The immediate requirements for a conservation programme for swamp deer in Uttar Pradesh are:

(a) an etho-ecological study of the deer, with particular reference to their seasonal needs and movements, to provide a basis either for 
extension of Dudwa Sanctuary to include the deer's entire annual range, or to restrict the animals to the present sanctuary area, including presently unoccupied grassland.

(b) the eviction of graziers along the southern grassland belt of Dudwa and the establishment of a chain of guard posts on the boundary to prevent unauthorised grazing incursions and eliminate poaching. Mr Arjan Singh should be appointed an Honorary Wildlife Warden and invited to participate in the scheme.

(c) all further tree planting in the few remaining swamp deer habitats to be halted and a programme prepared by the Wildlife Section to ensure protection of the deer, including regular checks and reports on their status, elimination of poaching and restriction of grazing and human disturbance.

\section{Acknowledgments}

The writer is indebted to Mr Arjan Singh, Indian Wild Life Board, Mr M. K. Ranjitsinh, Deputy Secretary (Forests and Wild Life), Government of India, Mr B. H. Hingorani, Conservator of Forests (Wildlife), Mr S. C. Sharma, Wild Life Warden, Kheri Region, Mr Y. P. Varshney, Assistant Wild Life Warden, Dudwa, and to numerous members of the Wild Life Section and regular Forest Department staff of Uttar Pradesh State, for their hospitality, unfailing courtesy, and the considerable time and effort that they expended to assist him in the collection of information.

\section{References}

ELLERMAN, J. and T. MORRISON-SCOTT. 1951. Checklist of Palaearctic and Indian Mammals, 1758 to 1946.

SCHALLER, G.B. 1967. The Deer and the Tiger. Chicago University Press.

SINGH, A. 1970. The Swamp Deer of North Kheri. IUCN 11th Tech. Meeting. Vol. 2. Problems of Threatened Species. IUCN Pub. new series 18, pages $52-54$.

\section{Plan for the Indian Lion}

The Gujarat Government in north-western India deserve warm congratulations for their broad-minded approach to the problem of the Indian lion, now reduced to some 300-odd animals in the Gir Forest in their State, and they have published a small book The Gir Lion Sanctuary Project, full of historical information about the lion, and outlining the plan for the restoration of the Gir habitat, by Guy Mountfort, now being implemented with the help of a substantial gift from the Mzuri Safari Club Foundation. As Zafar Futehally remarks in this book, 'the future of the lion is in good hands'.

\section{IUCN Publications}

The papers and proceedings of five valuable conferences or meetings of experts are published by the International Union for Conservation of Nature (IUCN), in Morges. These are the Madagascar meeting in October 1970 ( $£ 0.85, \$ 2.00)$; the Calgary meeting on Bear Biology and Management in November $1970,(£ 3.70, \$ 9.00)$; the first working meeting of the Crocodile Specialist Group in New York, March 1971 (2 vols. £0.85, \$2.00); the final report of the European working conference on Environmental Conservation Education in December 1971, and the third working meeting of the Polar Bear Specialist Group in February 1972 ( $£ 0.85, \$ 2.00)$. 